\title{
Postępy w leczeniu dorosłych chorych na ostre białaczki
}

\section{Advances in the treatment of adult patients with acute leukemias}

\author{
Agnieszka Wierzbowska \\ Katedra i Klinika Hematologii, Uniwersytet Medyczny, Łódź
}

\begin{abstract}
Streszczenie
W ostatnich latach dokonat sie istotny postęp w zrozumieniu molekularnych mechanizmów patogenezy ostrych biataczek oraz poznaniu nowych czynników prognostycznych. Wiedza ta stworzyta podstawy do rozwoju nowoczesnych leków i bardziej skutecznych metod leczenia. Istnieja dowody na to, że poprawa jakości remisji wiqże się z obniżeniem ryzyka nawrotu biataczki. Nowe strategie leczenia indukujacego zwiazane z eskalacja dawek daunorubicyny, dotaczeniem analogów nukleozydowych lub przeciwciat monoklonalnych charakteryzuja sie wyższa skutecznościa niż standardowa chemioterapia $3+7$ u chorych na ostre biataczki szpikowe (AML) poniżej 60. roku życia. Odmiennie jest u starszych chorych leczonych mniej intensywnie — uzyskanie catkowitej remisji nie jest dobrym surogatem catkowitego przeżycia. Wykazano, że leki hipometylujace istotnie wydtuzaja przezycie chorych na AML, bez istotnej poprawy odsetka remisji. Rokowanie chorych na ostra biataczke limfoblastyczna (ALL) u dorostych jest nadal niezadowalajace, a leczenie tej grupy chorych stanowi wyzwanie dla wspótczesnej medycyny. Nowe technologie medyczne, w tym terapie celowane i immunoterapia przeciwciałami monoklonalnymi lub limfocytami CAR, sa niezwykle obiecujace $i$ daja wielkie nadzieje na poprawe rokowania $w$ ALL u dorostych. W pracy przedstawiono krótki przeglad nowych strategii leczniczych stosowanych u chorych na ostre biataczki w ostatnich latach.
\end{abstract} Słowa kluczowe: ostra białaczka szpikowa, ostra białaczka limfoblastyczna, chemioterapia, przeciwciała monoklonalne, terapia celowana, limfocyty CAR

Hematologia 2015; 6, 1: 52-62

\begin{abstract}
Significant progress has been made within the last years in elucidating and understanding the molecular pathogenesis of acute leukemias and for identifying factors predictive of outcome. Such achievements have thereby provided new opportunities for developing innovative and more effective drugs. There is also evidence that improving the quality of remission can reduce the risk of relapse. New and more effective induction strategies of increasing the daunorubicin dose, introducing antibody-directed chemotherapy and alternative nucleoside analogs may displace the longstanding standard $3+7$ chemotherapy in patients aged below 60 years suffering acute myeloid leukemia (AML). An unexpected recent finding has been that complete remission in elderly AML patients may not necessarily translate into an overall survival advantage. Hypomethylating agents have demonstrated survival benefit without any improvement in remission rate. The prognosis of adults with acute lymphoblastic leukemia (ALL) is still not satisfactory and adult ALL still remains a challenging disease. Novel methodologies, including new molecular therapeutic targets, immu-
\end{abstract}

Adres do korespondencji: Agnieszka Wierzbowska, Katedra i Klinika Hematologii, Uniwersytet Medyczny, Wojewódzki Szpital Specjalistyczny im. Mikołaja Kopernika, ul. Ciołkowskiego 2, 93-510 Łódź, e-mail: agawierzbowska@wp.pl 
notherapy with monoclonal antibodies or CAR lymphocytes are very promising for improving ALL patient prognosis. This paper provides a summary review of current insights into new therapeutic strategies for acute leukemias.

Key words: acute myeloid leukemia, acute lymphoblastic leukemia, chemotherapy,
monoclonal antibobody, targeted therapy, CAR lymphocytes

Hematologia 2015; 6, 1: 52-62

\section{Wprowadzenie}

W ostatnich dwóch dekadach dokonał się istotny postęp w zrozumieniu molekularnych mechanizmów patogenezy ostrych białaczek oraz poznaniu nowych czynników prognostycznych. Wiedza ta stworzyła podstawy do rozwoju nowoczesnych leków i bardziej skutecznych metod leczenia. Główne kierunki badań obejmują zagadnienia związane z: 1) możliwością poprawy wyników standardowej chemioterapii; 2) rolą przeszczepienia krwiotwórczych komórek macierzystych (HSCT, hematopoietic stem cells transplantation) w leczeniu ostrych białaczek; 3) poszukiwaniem nowych leków i terapii celowanej oraz 4) wykorzystaniem różnych form immunoterapii.

\section{Ostra białaczka szpikowa}

Ostra białaczka szpikowa (AML, acute myeloid leukemia) jest chorobą, w której dochodzi do proliferacji i kumulacji w szpiku kostnym niedojrzałych komórek blastycznych, wywodzących się ze stransformowanej nowotworowo prekursorowej komórki mieloidalnej. $\mathrm{W}$ ostatnich latach nastąpił znaczny postęp w zrozumieniu biologii i patogenezy AML, który uwidocznił ogromną heterogenność tej grupy chorób. W aktualnej klasyfikacji Światowej Organizacji Zdrowia (WHO, World Health Organization) wyróżnia się ponad 20 różnych podtypów AML definiowanych na podstawie odrębnych cech genetycznych i cytomorfologicznych. W związku z powyższym niemożliwe jest opracowanie jednej skutecznej terapii celowanej. Konieczne są zatem zarówno optymalizacja standardowych protokołów chemioterapii wspólnych dla dużych grup pacjentów $z$ AML, jak i indywidualizacja podejścia terapeutycznego uwzględniająca określone aberracje genetyczne lub cechy immunofenotypowe. W ostatnich latach potwierdzono zasadność dostosowania intensywności leczenia do szacowanego ryzyka nawrotu, wieku i stanu biologicznego pacjenta. Podkreśla się również konieczność indywidualizacji terapii $z$ wykorzystywania nowych leków w celu poprawy odległych wyników leczenia.

\author{
Leczenie chorych na AML \\ poniżej 60. roku życia
}

Podstawą chemioterapii indukującej w AML jest antybiotyk antracyklinowy podawany przez 3 kolejne dni w skojarzeniu $\mathrm{z}$ arabinozydem cytozyny (Ara-C) stosowanym przez $7 \mathrm{dni}$. Leczenie to (tzw. terapia ,3 3 7”) pozwala na uzyskanie całkowitej remisji (CR) u 60-80\%. Najczęściej stosowaną antracykliną jest daunorubicyna (DNR) w dawce $45-60 \mathrm{mg} / \mathrm{m}^{2} /$ dobę lub idarubicyna (IDA) w dawce $10-12 \mathrm{mg} / \mathrm{m}^{2} /$ dobę przez 3 kolejne dni. W ostatnich latach podejmowano próby poprawy skuteczności standardowych protokołów chemioterapii indukującej [1].

W randomizowanym badaniu ECOG 1900 [2] wykazano, że eskalacja dawki DNR z 45 do $90 \mathrm{mg} / \mathrm{m}^{2}$ umożliwia uzyskanie wyższego odsetka CR i wydłużenie mediany czasu przeżycia całkowitego (OS, overall survival). W dodatkowej analizie w podgrupach ryzyka cytogenetycznego stwierdzono jednak, że beneficjentem leczenia $z$ zastosowaniem większych dawek DNR są jedynie chorzy z grup korzystnego i pośredniego ryzyka. Autorzy postulowali rozważenie schematu DNR $90 \mathrm{mg} / \mathrm{m}^{2}(3 \mathrm{dni})+$ Ara-C $100 \mathrm{mg} / \mathrm{m}^{2}$ (7 dni) jako nowego standardu leczenia indukującego, podkreślali jednak również konieczność dalszych badań służących ocenie skuteczności DNR w dawce $60 \mathrm{mg} / \mathrm{m}^{2}$ i Ara-C $\left(200 \mathrm{mg} / \mathrm{m}^{2}\right)$.

Poszukiwanie optymalnej dawki DNR było również przedmiotem prospektywnego, randomizowanego badania grupy MRC (UK NCRI AML17) [3]. Porównano w nim skuteczność i toksyczność DNR w dawce $90 \mathrm{mg} / \mathrm{m}^{2} \mathrm{z}$ dawką $60 \mathrm{mg} / \mathrm{m}^{2}$ w leczeniu indukującym $\mathrm{u}$ chorych na nowo rozpoznaną AML. Odsetek CR w obu grupach był porównywalny $(81 \% v .84 \%)$. U chorych leczonych większymi dawkami DNR obserwowano istotnie wyższą śmiertelność wczesną (ED, early death) w ciągu 60 dni od rozpoczęcia leczenia ( $10 \%$ v. 5\%; $\mathrm{p}=0,001)$. Główną przyczyną zgonów były powikłania głębokiej mielosupresji, takie jak ciężkie infekcje i krwawienia. Przeżycie wolne od nawrotu (RFS, relapse-free survival), skumulowane ryzyko 
nawrotu (CIR, cumulative incidence of relapse) oraz OS w obu grupach były porównywalne. Nie obserwowano korzyści z eskalacji dawki DNR w podgrupach definiowanych na podstawie ryzyka cytogenetycznego, wieku ( $>60 v$. <60. rż.), leukocytozy $(<10 v .>10 \mathrm{G} / \mathrm{L})$ lub liczby płytek $(>50$ $v$. $<50 \mathrm{G} / \mathrm{L})$. Obserwacje te wskazują, że zwiększenie dawki DNR z $60 \mathrm{mg} / \mathrm{m}^{2}$ do $90 \mathrm{mg} / \mathrm{m}^{2}$ w leczeniu indukującym nie wiąże się $z$ poprawą OS u chorych na nowo rozpoznaną AML.

Alternatywą dla eskalacji dawek DNR w protokole $3+7$ może być dołączenie trzeciego leku o synergistycznym lub komplementarnym mechanizmie działania. W badaniach PALG (Polish Adult Leukemia Group) wykazano korzystny wpływ dodania kladrybiny w dawce $5 \mathrm{mg} / \mathrm{m}^{2} /$ dobę w 2-godzinnej infuzji przez 5 kolejnych dni do protokołu , $3+7 ”$ (protokół DAC). W grupie leczonej DAC obserwowano znamiennie wyższy odsetek CR $(67,5 \%)$ i rzadsze występowanie pierwotnej oporności na chemioterapię $(21 \%) \mathrm{w}$ porównaniu $\mathrm{z}$ leczonymi standardową terapią $3+7$ (odpowiednio 56\%; $\mathrm{p}=0,01$ i $34 \%$; $\mathrm{p}=0,004)$. Dołączenie kladrybiny miało również istotny wpływ na poprawę OS (3-letni OS $45 \%$ v. 33\%), w szczególności u chorych powyżej 50. roku życia, $z$ wysoką leukocytozą ( $>50 \mathrm{G} / \mathrm{L}$ ) oraz w grupie $z$ niekorzystnym kariotypem [4]. Na podstawie wyników badania PALG leczenie indukujące DAC otrzymało 1. poziom rekomendacji według NCCN (National Comprehensive Cancer Center Network) w leczeniu chorych na AML.

Stosowanie gemtuzumabu ozogamycyny (GO; Mylotarg ${ }^{\circledR}$ ) w leczeniu AML budziło w ostatnich latach wiele kontrowersji, głównie $z$ powodu sprzecznych wyników dotychczas publikowanych badań. Na konferencji ASH (American Society of Hematology) w 2013 roku przedstawiono wyniki metaanalizy 5 dużych randomizowanych badań, w których GO stosowano w skojarzeniu ze standardową chemioterapią indukującą [5]. W metaanalizie uwzględniono dane poszczególnych pacjentów leczonych w badaniu grupy amerykańskiej (SWOG-0106), francuskiej (ALFA-0701), w dwóch badaniach grupy brytyjskiej (UK MRC/NCRI AML15 \& 16) oraz badaniu grupy GOELAMS (AML2006IR). Łącznie analizą objęto 3339 chorych w wieku do 84 lat. Wykazano, że dołączenie GO do standardowej chemioterapii indukującej nie wplywa na odsetek CR, natomiast nieznamiennie zwiększa ryzyko zgonu w ciągu pierwszych 30 dni leczenia $(\mathrm{p}=0,08)$. W grupie chorych leczonych GO stwierdzono poprawę przeżycia od momentu uzyskania remisji $(\mathrm{p}=0,001)$ oraz wydłużenie OS $(\mathrm{p}=0,01)$, głównie $\mathrm{w}$ wyniku znaczącej redukcji odsetka nawrotów ( $\mathrm{p}=0,00006)$. Nie obserwowano istotnego zróżnicowania między poszczególnymi badaniami, choć istnieją sugestie wskazujące na nieznacznie wyższą śmiertelność wczesną u chorych leczonych większymi dawkami GO. Głównymi beneficjentami leczenia skojarzonego byli chorzy z grup korzystnego i pośredniego ryzyka cytogenetycznego. W podsumowaniu należy stwierdzić, że dołączenie GO do standardowej terapii indukującej wydłuża OS u większości chorych na AML, a w szczególności u chorych na białaczki z grupy $\mathrm{CBF}$ (core-binding factor) oraz że korzyść ta przewyższa ewentualne ryzyko wczesnego zgonu. Podobne wnioski wynikają $z$ retrospektywnej analizy brytyjskiej grupy MRC [6], w której podsumowano wyniki leczenia chorych $z$ CBF-AML poddawanych terapii $\mathrm{w}$ badaniach MRC AML10, 12, 15 oraz NCRI AML17 w ostatnich 25 latach. Analizą objęto 896 chorych $z$ CBF-AML. W analizie wielowariantowej wykazano, że dołączenie GO do standardowej terapii indukującej $(\mathrm{p}<0,0001)$, stan ogólny $(\mathrm{p}=0,001)$, wiek $(\mathrm{p}=0,001)$ oraz logarytm leukocytozy $(\mathrm{p}=0,002)$ istotnie wpływały na poprawę odległych wyników leczenia. Obserwacje te wskazują, że wprowadzenie do indukcji GO i utrzymanie w konsolidacji dużych dawek Ara-C (HD-Ara-C, high-dose Ara-C) miało największy wpływ na poprawę wyników leczenia u chorych na CBF-AML w ostatnich latach.

Ocena skuteczności HD-Ara-C w leczeniu indukującym była również przedmiotem intensywnych badań. W badaniu grupy MRC (AML15) porównano skuteczność standardowych dawek Ara-C (protokół ADE [Ara-C, DNR, etopozyd]) i HD-Ara-C (protokół FLAG-IDA [fludarabina, HD-Ara-C, idarubicyna, G-CSF]) u chorych $z$ nowo rozpoznaną AML i również nie wykazano różnicy w odsetku CR [7]. Leczenie indukujące FLAG-IDA wiązało się wprawdzie $z$ wyższym odsetkiem CR po pierwszym kursie leczenia, niższym odsetkiem nawrotów i poprawą RFS, prowadziło jednak do znacznej mielosupresji. Konsekwencją głębokiej mielosupresji po leczeniu FLAG-IDA był wyższy odsetek zgonów w CR i brak różnicy w OS. Podobnie w badaniu grupy HOVON/SAKK (Dutch-Belgian Cooperative Trial Group for Hemato-Oncology/Swiss Group for Clinical Cancer Research) nie potwierdzono korzyści ze stosowania HD-Ara-C w leczeniu indukującym w żadnej grupie rokowniczej, natomiast wykazano istotnie wyższy odsetek ciężkich zdarzeń niepożądanych, dłuższy czas regeneracji granulocytów i płytek oraz dłuższy czas hospitalizacji chorych leczonych większymi dawkami Ara-C [8]. 
Na podstawie wyników badań klinicznych prezentowanych w ostatnich latach można stwierdzić, że jest możliwa modyfikacja dotychczasowego standardu leczenia indukującego $3+7$. Obecnie za optymalny schemat leczenia należy przyjąć protokół DAC lub chemioterapię $3+7$ z DNR w dawce $60-90 \mathrm{mg} / \mathrm{m}^{2}$ przez 3 kolejne dni. U chorych na białaczkęą $z$ grupy CBF warto rozważyć leczenie indukujące w skojarzeniu $z$ GO.

\section{Leczenie chorych na AML powyżej 60. roku życia}

Wyniki leczenia AML u chorych starszych nie zmieniły się istotnie i pozostają niezadowalające. Gorsze rokowanie wynika $z$ odmiennej biologii AML u starszych chorych, a także wspólistnienia innych osobniczozależnych czynników; AML u osób powyżej 60. roku życia wywodzi się $z$ młodszych komórek prekursorowych układu krwiotwórczego, charakteryzuje się znaczną lekoopornością i upośledzoną odnową hematopoezy, a także częstym występowaniem niekorzystnych aberracji cytogenetycznych. W tej grupie wiekowej biologiczne cechy AML, bardziej niż sam wiek, decydują o gorszej odpowiedzi na leczenie i złym rokowaniu. Punktem wyjścia do planowania prospektywnych badań klinicznych u chorych z AML powyżej 60. roku życia jest odpowiednia stratyfikacja chorych uwzględniająca czynniki predykcyjne wczesnego zgonu i lekooporności. Chorzy w dobrym stanie ogólnym (PS 0-2) z niskim wskaźnikiem HCT-CI (hematopoietic cells transplantation-comorbidity index), bez niekorzystnych aberracji cytogenetycznych, powinni otrzymać intensywną chemioterapię $z$ uwzględnieniem możliwości wykonania przeszczepienia allogenicznych krwiotwórczych komórek macierzystych ze zredukowanym kondycjonowaniem (RIC-allo-HSCT, reduced-intensity conditioning allogeneic stem cells transplantation). Chorzy w gorszym stanie ogólnym i/lub z niekorzystną cytogenetyką mają nikłe szanse na powodzenie standardowej chemioterapii i powinni być leczeni nowymi lekami w ramach badań klinicznych [1].

W ostatnich latach wiele uwagi poświęca się inhibitorom metylotransferazy DNA, takim jak azacytydyna (AZA) czy decytabina (DEC). W prospektywnym, randomizowanym badaniu 3. fazy Kantarijan i wsp. [9] porównali skuteczność DEC z małymi dawkami cytarabiny (LD-Ara-C, low-dose Ara-C) i/lub najlepszym leczeniem wspomagającym u starszych chorych (> 65. rż.) z nowo rozpoznaną AML, którzy nie kwalifikowali się do intensywnej chemioterapii. W grupie leczonej DEC, w porównaniu z grupą kontrolną, stwierdzono wyższy odsetek remisji $(17,8 \%$ v. $7.8 \%$ ) i dłuższe OS (mediana 7,7 miesiąca $v .5,0$ miesięcy).

Wyniki prospektywnego, randomizowanego badania 3. fazy AZA-AML-001, w którym porównano skuteczność AZA i konwencjonalnej chemioterapii (CCR, conventional chemotherapy) $\mathrm{w}$ tym intensywnej chemioterapii, LD-Ara-C i najlepszego leczenia wspomagającego (BSC, best supportive care), wskazują, że leczenie AZA o 4 miesiące wydłuża medianę OS w porównaniu z CCR u mających ponad 65 lat chorych na AML $z$ odsetkiem blastów w szpiku powyżej 30\%. Potwierdzono również wysoką skuteczność AZA u chorych o wybitnie niekorzystnym rokowaniu, takich jak pacjenci $z:$ 1) AML $z$ towarzyszącymi morfologicznymi cechami dysplazji w szpiku (AML-MDC, AML-morphologic dysplastic changes) [10] lub 2) AML z niekorzystnymi aberracjami genetycznymi [11]. W grupie AML-MDC leczenie AZA wiązało się z 2-krotnym wydłużeniem mediany OS (12,7 miesiąca) w porównaniu z CCR (6,3 miesięcy; $\mathrm{p}<0,04)$. Podobnie prawdopodobieństwo przeżycia roku w grupie leczonej AZA było wyższe niż u leczonych CCR (50,7\% v. 33,8\%). Odsetek CR $\mathrm{u}$ chorych leczonych AZA był również wyższy niż w grupie leczonej standardowo (26,7\% v. 19,3\%), jednak różnica ta nie osiągnęła znamienności statystycznej. Toksyczność hematologiczna była porównywalna w obu grupach. Podobnie u chorych obciążonych wysokim ryzykiem cytogenetycznym mediana OS w grupie leczonej AZA była 2-krotnie wyższa niż u chorych leczonych konwencjonalnie (odpowiednio 6,4 v. 3,2 miesiąca; $\mathrm{p}=0,019$ ). $\mathrm{W}$ grupie pośredniego ryzyka cytogenetycznego mediana OS w grupie leczonej AZA również była wyższa, lecz różnica nie osiągnęła znamienności statystycznej (13,0 v. 10,1 miesiąca; $\mathrm{p}=0,41)$. Prawdopodobieństwo przeżycia roku u chorych leczonych AZA również było 2-krotnie większe niż w grupie leczonej CCR (odpowiednio 30,9\% v. 14,0\%). Wyniki badania AZA-AML001 potwierdzają wysoką skuteczność kliniczną AZA u chorych na AML wysokiego ryzyka i wskazują, że leczenie AZA stanowi atrakcyjną alternatywę dla LD-Ara-C. Wykazano także, że AZA nie tylko indukuje różnicowanie komórek białaczkowych, ale także zwiększa ekspresję antygenów HLA-DR i prawdopodobnie innych antygenów białaczkowych, może więc nasilać efekt przeszczep przeciwko białaczce (GvL, graft versus leukemia) u chorych po allo-HSCT. Wstępne obserwacje w małych grupach chorych są zachęcające i wskazują, że strategia 
ta może być też wykorzystana jako zapobieganie wznowie białaczki [12].

Wyniki badań $z$ ostatnich lat wskazują, że u starszych chorych leczonych mniej intensywnie uzyskanie CR nie jest dobrym czynnikiem predykcyjnym dłuższego OS. Potwierdzają to zarówno wyniki badania AZA-AML001, jak i randomizowane badanie służące porównaniu klofarabiny (CLO, clofarabine) $\mathrm{z}$ LD-Ara-C u chorych powyżej 50. roku życia zdyskwalifikowanych $z$ intensywnej chemioterapii [13]. Klofarabinę stosowano dożylnie w dawce $20 \mathrm{mg} / \mathrm{m}^{2} \mathrm{w}$ dniach 1.-5., LD-Ara-C zaś - w standardowej dawce $20 \mathrm{mg}$ podskórnie co 12 godzin w dniach 1.-10. Śmiertelność w ciągu 30 i 60 dni po leczeniu była wyższa w grupie leczonej CLO niż leczonej według protokołu LD-Ara-C (odpowiednio 18 v. 13\% i 32\% v. 26\%). Mimo wyższego odsetka CR w grupie leczonej CLO nie obserwowano istotnej różnicy OS w obu analizowanych grupach.

\section{Ostra białaczka promielocytowa}

Ostra białaczka promielocytowa (APL, acute promyelocytic leukemia) jest podtypem AML o odmiennej biologii, obrazie klinicznym i z dużą szansą na wyleczenie. Rokowanie w tej białaczce znacznie się poprawiło po wprowadzeniu do jej leczenia kwasu all-transretinowego (ATRA, all-trans-retinoic-acid) i trójtlenku arsenu (ATO, arsenic trioxide). Protokól AIDA (ATRA w skojarzeniu z IDA) był przez wiele lat „złotym standardem” leczenia indukującego u chorych na APL. Jednak wyniki randomizowanego badania grupy włosko-niemieckiej (APL0406) [14] sugerują zmianę standardu leczenia chorych na APL z grup niskiego i pośredniego ryzyka (leukocytoza $<10 \mathrm{G} / \mathrm{L}$ ). W badaniu porównywano skuteczność terapii ATO w skojarzeniu z ATRA ze standardowym leczeniem indukującym AIDA u 254 chorych. W grupie eksperymentalnej chorzy otrzymywali ATO $\mathrm{w}$ dawce 0,15/kg mc. + ATRA $45 \mathrm{mg} / \mathrm{m}^{2} /$ dobę aż do czasu uzyskania CR, a następnie ATO przez 5 dni $\mathrm{w}$ tygodniu, przez 28 kolejnych dni co 4 tygodnie (4 cykle) i ATRA przez 2 tygodnie co 28 dni (7 cykli). Wszyscy chorzy z grupy leczonej ATO i $97 \%$ z grupy leczonej AIDA uzyskało CR. W grupie leczonej AIDA, z powodu powikłań chemioterapii, 4 chorych zmarło, 2-letnie przeżycie wolne od zdarzeń (EFS, event-free survival) w grupie leczonej ATO + ATRA było istotnie wyższe niż w grupie, w której stosowano protokół AIDA (98\% v. 84,9\%; $\mathrm{p}=0,0002)$. Podobnie $\mathrm{w}$ grupie leczonej ATO + ATRA obserwowano istotnie niższe skumulowane ryzyko nawrotu (odpowiednio 1,1\% v. $9,4 \% ; \mathrm{p}=0,005)$. Całkowite przeżycie $\mathrm{w}$ grupie chorych leczonych ATO było dłuższe niż u chorych leczonych standardowo $(99,1 \%$ v. $94,4 \% ; \mathrm{p}=0,01)$. Przewaga skojarzonego leczenia ATO + ATRA nad standardowym leczeniem indukującym AIDA wskazuje, że leczenie celowane oparte na dwóch lekach o odmiennym mechanizmie działania powinno być nowym standardem leczenia chorych na APL $z$ grup niskiego i pośredniego ryzyka [15].

\section{Terapie celowane i nowe leki}

Mutacje i aberracje genetyczne odgrywają istotną rolę w biologii AML. Markery te nie tylko pozwalają definiować odrębne jednostki kliniczno-patogenetyczne, lecz także mają istotne znaczenie rokownicze oraz coraz częściej zasadniczo wpływają na wybór określonej strategii terapeutycznej. Wiele innych mutacji somatycznych związanych $z$ białaczką (m.in. FLT3-ITD, NPM1, CEBPA, c-KIT) ma znaczenie w praktyce klinicznej i determinuje kierunki rozwoju nowych badań.

Gen FLT3 koduje błonowe białko należące do III klasy receptorów kinazy tyrozynowej i bierze udział w proliferacji, różnicowaniu i apoptozie prekursorów komórek krwiotwórczych. Nabyte mutacje genu FLT3 stwierdza się u 30-35\% chorych na AML. Do najczęściej spotykanych mutacji genu FLT3 należy wewnętrzna tandemowa duplikacja (ITD, internal tandem duplication) części przybłonowej. Jej rezultatem jest stałe pobudzenie szlaków kinazy MAPK (mitogen-activated protein kinase) fałszywie dających sygnały do niekontrolowanej proliferacji komórek. Wewnętrzne tandemowe duplikacje są niezależnym, niekorzystnym czynnikiem rokowniczym dla czasu trwania CR i OS. Szczególnie niekorzystne rokowanie opisywano $\mathrm{u}$ chorych $\mathrm{z}$ dużą masą zmutowanego allelu FLT3-ITD [16-18].

Stosowane w ramach badań klinicznych inhibitory kinazy FLT3, takie jak midostaurin (PKC-412), lestaurtynib (CEP-701), sunitynib (SU11248) czy sorafenib (BAY-43-9006), wykazują umiarkowaną aktywność przeciwbiałaczkową w monoterapii. Obecnie wielkie nadzieje na leczenie AML z FLT3-ITD są wiązane $z$ inhibitorami II generacji. U chorych na oporną i nawrotową AML z FLT3-ITD wykazano wysoką skuteczność quizartinibu (AC220) w monoterapii [19, 20]. Niezwykle zachęcające są wyniki badania służącego ocenie bezpieczeństwa i skuteczności AC220 u 62 chorych na oporną i nawrotową AML z FLT3-ITD [21]. Wyniki leczenia oceniano w dwóch grupach chorych: 1) starszych (> 60. rż.), z nawrotem lub $z$ opornością na co naj- 
mniej jedną linię leczenia; 2) młodszych (<60. rż.), $z$ opornością lub nawrotem po dwóch liniach leczenia lub po HSCT. Łączny odsetek uzyskiwanych CR wynosił $45 \%$; u $24 \%$ chorych uzyskano częściową remisję (PR, partial remission). Należy podkreślić, że 16 z 26 (62\%) chorych opornych na co najmniej jedną linię leczenia uzyskało CR. Do najczęstszych objawów niepożądanych należały: nudności, wymioty, zmęczenie, wydłużenie odstępu QT, brak apetytu, gorączka, neutropenia i zaburzenia smaku. Prowadzone jest również badanie w celu oceny skuteczności selektywnego inhibitora FLT-3 (quizartinibu) w skojarzeniu ze standardową chemioterapią indukującą według protokołu ADE u chorych na AML powyżej 60. roku życia.

Obecność mutacji c-KIT lub nadmiernej ekspresji c-KIT u chorych na CBF-AML jest niekorzystnym czynnikiem prognostycznym i koreluje $z$ wyższym odsetkiem nawrotów. W prospektywnym badania 2 . fazy grupy CALGB, w którym oceniono skuteczność i toksyczność standardowej chemioterapii $\mathrm{w}$ skojarzeniu $z$ inhibitorem c-KIT (dazatynib [DAS, dasatinib]) u 61 chorych $z$ nowo rozpoznaną, potwierdzoną molekularnie CBF-AML [22]. Chorzy otrzymywali standardowe leczenie indukujące $7+3\left(\right.$ Ara-C $200 \mathrm{mg} / \mathrm{m}^{2} / \mathrm{d}$. w dniach 1.-7.i DNR $60 \mathrm{mg} / \mathrm{m}^{2} / \mathrm{d}$. w dniach 1.-3.) w skojarzeniu $z$ DAS w dawce $100 \mathrm{mg} /$ dobę (od 8. do 21. dnia). Chorzy, którzy uzyskali CR, otrzymywali 4 kursy konsolidujące $z$ dużymi $(<60$. rż.) lub pośrednimi ( $\geq 60$. rż.) dawkami Ara-C w skojarzeniu z DAS w dawce $100 \mathrm{mg} /$ dobę przez 21 dni. Całkowitą remisję uzyskało 54 z 59 chorych (92\%). Prawdopodobieństwo przeżycia 2 lat bez objawów choroby i OS wynosiły odpowiednio $72 \%$ i $87 \%$ i były wyższe w grupie chorych młodszych niż w populacji osób starszych. Wyniki leczenia skojarzonego u chorych z mutacją c-KIT są porównywalne do uzyskanych w grupie bez mutacji c-KIT co pośrednio wskazuje, że dołączenie DAS przełamuje niekorzystny działanie mutacji c-KIT w CBF-AML.

$\mathrm{W}$ prospektywnym, randomizowanym badaniu SORAML oceniono skuteczność i toksyczność dołączenia inhibitora wielu kinaz tyrozynowych — sorafenibu (SOR) — do standardowego leczenia indukującego i konsolidującego u mających mniej niż 60 lat chorych na AML [23]. Analizą objęto 276 chorych w wieku 18-60 lat; wszyscy otrzymywali 2 cykle indukujące $z 3+7$, a następnie 3 cykle konsolidujące HD-Ara-C. Chorych poddano randomizacji do grupy leczenia skojarzonego z SOR w dawce $800 \mathrm{mg} /$ dobę lub terapii standardowej z placebo; SOR/placebo stosowano od 10. do 19. doby każdego cyklu indukującego i od 8. doby każdego cyklu konsolidującego. Po zakończeniu konsolidacji chorzy otrzymywali SOR/placebo w leczeniu podtrzymującym przez kolejne 12 miesięcy. Odsetek CR w obu grupach był porównywalny (59\% w grupie otrzymującej placebo i $60 \%$ $\mathrm{w}$ grupie leczonej SOR). Wykazano, że mediana EFS i 3-letnie EFS u chorych leczonych SOR były istotnie większe niż $\mathrm{w}$ grupie przyjmującej placebo (20,5 v. 9,2 miesięcy). W grupie poddanej terapii skojarzonej obserwowano również wyższe 3-letnie OS (63\%) w porównaniu $z$ grupą kontrolną (56\%), różnica ta nie osiągnęła jednak znamienności statystycznej. Wyniki badania wskazują, że dołączenie SOR do standardowej terapii zwiększa skuteczność stosowanego leczenia oraz istotnie wydłuża EFS i przeżycie wolne od nawrotu (RFS, relapse-free survival), natomiast nie wydłuża OS.

\section{Nowe kierunki rozwoju leczenia chorych na AML}

\section{Eliminacja białaczkowych \\ komórek macierzystych}

U chorych poniżej 60. roku życia odsetki $\mathrm{CR}$ po zastosowaniu standardowej chemioterapii indukującej $3+7$ wynoszą $75-80 \%$, natomiast u ponad połowy chorych dochodzi do nawrotu w pierwszych 3 latach po leczeniu. Celem leczenia poremisyjnego jest eradykacja minimalnej choroby resztkowej (MRD, minimal residual disease), a zwłaszcza chemioopornych białaczkowych komórek macierzystych (LSC, leukemic stem cells), które są głównym źródłem nawrotu. Odkrycie LSC stworzyło podstawy dla lepszego zrozumienia biologii AML [24, 25]. Wstępne badania wskazują, że LSC charakteryzują się niskim potencjałem proliferacyjnym i w konsekwencji większą niż pozostała masa komórek białaczkowych opornością na chemioterapię. Przypuszcza się, że eliminacja LSC jest warunkiem uzyskania trwałej remisji i wyleczenia chorych na AML; LSC charakteryzuje między innymi nadmierna ekspresja CD123 (łańcuch alfa receptora interleukiny 3 [IL-3]). W badaniu 1. fazy prezentowanym na konferencji ASH w 2014 roku oceniono bezpieczeństwo, farmakokinetykę i immunogenność humanizowanego przeciwciała monoklonalnego anty-CD123 (CSL362) $\mathrm{w}$ leczeniu poremisyjnym $\mathrm{u}$ chorych na AML CD123+ w pierwszej CR (CR1) lub w drugiej CR (CR2) obciążonych wysokim ryzykiem nawrotu (ocenianym na podstawie przebiegu choroby, badań cytogenetycznych i molekularnych oraz oceny MRD), którzy nie są kandydatami do allo-HSCT [26]. Przeciwciało monoklonalne anty-CD123 
stosowano dożylnie w 3-godzinnym wlewie co 14 dni (łącznie 6 dawek). Ocenę bezpieczeństwa przeprowadzano w 16 . tygodniu leczenia, a ocenę odpowiedzi - w 24. tygodniu terapii. Przeciwciało w stopniowo zwiększanych dawkach, od 0,3 do $9,0 \mathrm{mg} /$ /kg mc., stosowano w kohortach (3-6-osobowych). Analizą objęto 25 chorych w wieku 32-83 lat (mediana 66 lat); łącznie podano 118 infuzji CSL362. Do najczęstszych zdarzeń niepożądanych związanych z CSL362, należały: reakcje związane $z$ infuzją, wzrost stężenia białka C-reaktywnego, wzrost lub spadek ciśnienia tętniczego. Działania niepożądane związane $z$ infuzją były dobrze kontrolowane za pomocą leczenia wspomagającego, między innymi glikokortykosteroidami. Mediana czasu trwania CR wynosiła ponad 34 tygodnie; u 3 spośród 6 chorych z MRD obserwowano jej eliminację. W badaniach farmakodynamiki wykazano, że dawki CSL362 wynoszące $3,0 \mathrm{mg} / \mathrm{kg} \mathrm{mc}$. lub więcej powodują trwałe wysycenie CD123 na komórkach. Wyniki badania wskazują, że CSL362 jest dobrze tolerowane i może być bezpiecznie podawany chorym na AML w CR o wysokim ryzyku nawrotu i będą stosowane w zaplanowanych badaniach 2 . fazy.

Białaczkowe komórki macierzyste, podobnie jak prawidłowe macierzyste komórki krwiotwórcze, rezydują w szpiku kostnym w tak zwanych niszach krwiotwórczych (HN, hematopoietic niche). $\mathrm{W}$ badań in vitro wynika, że interakcja $\mathrm{z}$ białkami HN chroni LSC przed toksycznym działaniem cytostatyków, a także pośredniczy w nabywaniu nowych mechanizmów oporności na chemioterapię. Istnieją dowody na to, że oddziaływanie między SDF-1 (CXCL12) a receptorem CXCR4 odgrywa kluczową rolę w obrębie mikrośrodowiska szpiku kostnego i w istotny sposób przyczynia się do rozwoju oporności LSC na chemioterapię [27, 28]. Aktywacja receptora CXCR4 na powierzchni LSC skutkuje ich migracją i osiedlaniem w obrębie HN, nasileniem adhezji i zahamowaniem dojrzewania. Zablokowanie CXCR4 prowadzi do mobilizacji LSC do krwi obwodowej. Ponadto wykazano, że ekspresja CXCR4 na blastach białaczkowych jest znamiennie wyższa niż na prawidłowych komórkach macierzystych i pozostaje niekorzystnym czynnikiem prognostycznym. Powyższe dane wskazują, że ingerencja w szlak sygnałowy SDF-1/CXCR4 może prowadzić do sensytyzacji i eradykacji LSC poprzez zaburzenie protekcyjnego wpływu mikrośrodowiska szpiku [29, 30].

W badaniach klinicznych prezentowanych na konferencji ASH w 2014 roku wykazano, że antagonista receptora CXCR4 (BL-8040) indukuje mobilizację komórek białaczkowych do krążenia i ich apoptozę u chorych na oporną/nawrotową AML [31]. Według protokołu chorzy otrzymywali BL-8040 podskórnie raz dziennie $\mathrm{w}$ monoterapii przez 1-2 dni, a następnie w skojarzeniu $z$ Ara-C $\left(1,5 \mathrm{~g} / \mathrm{m}^{2}\right.$ chorzy $\geq 60$. rż.; $3 \mathrm{~g} / \mathrm{m}^{2}$ chorzy $\leq 60$. rż. $)$ przez 5 kolejnych dni. Badania za pomocą cytometrii przepływowej wykazały, że już dwie dawki BL-8040 wystarczają do istotnej mobilizacji blastów białaczkowych ze szpiku do krwi obwodowej. Wzrostowi liczby blastów we krwi towarzyszyło jednoczesne, gwałtowne zmniejszenie liczby blastów w szpiku.

Humanizowane przeciwciało monoklonalne anty-CXCR4 (ulokuplumab) stosowano w skojarzeniu $z$ leczeniem reindukującym MEC (mitoksantron, etopozyd, cytarabina) u chorych na oporną i nawrotową AML [32]. Ulokuplumab podawano w zwiększanych dawkach $(0,3,1,3 \mathrm{lub} 10 \mathrm{mg} / \mathrm{kg} \mathrm{mc}$.) 7 dni przed rozpoczęciem chemioterapii, a następnie raz $\mathrm{w}$ tygodniu (3 dawki), począwszy od 1. dnia cyklu. Leczenie było dobrze tolerowane. Nie obserwowano toksyczności ograniczającej dawkę w monoterapii; odsetek CR wynosił $51 \%$. U 4 chorych remisję białaczki stwierdzono już po podaniu 1 dawki ulokuplumabu w monoterapii, co wskazuje na niezależne od chemioterapii działanie przeciwbiałaczkowe leku. Profil bezpieczeństwa leczenia skojarzonego był porównywalny do obserwowanego w przypadku samej chemioterapii.

\section{Limfocyty CAR}

W AML, podobnie jak w ALL, podejmuje się również próby opracowania limfocytów $\mathrm{T}$ CAR (chimeric antigen receptor) do zastosowania w terapii; CD123 jest antygenem obecnym na powierzchni większości pierwotnych komórek białaczkowych w AML, a w mniejszym stopniu — również na młodych, prawidłowych komórkach prekursorowych układu krwiotwórczego i dlatego wydaje się atrakcyjnym celem terapeutycznym immunoterapii limfocytami T CAR (CART) w AML. Niezwykle ciekawe $z$ perspektywy rozwoju nowych metod terapeutycznych są wyniki przedstawione na konferencji ASH w 2013 roku przez badaczy, którzy in vitro i in vivo ocenili bezpieczeństwo i możliwość stosowania limfocytów CART o swoistości anty-CD123 (CART123) w leczeniu AML [33]. W badaniach in vitro wykazano, że inkubacja komórek CART123 z blastami białaczkowymi prowadzi do specyficznej proliferacji CART123, niszczenia komórek białaczkowych i gwałtownej produkcji cytokin zapalnych. W badaniu na modelu zwierzęcym potwierdzono, że podanie CART123 myszom powoduje eliminację komórek 
białaczkowych i wydłuża przeżycie w porównaniu z grupą kontrolną; u myszy $z$ wszczepionymi prawidłowymi komórkami CD34+ przedłużona (28-dniowa) terapia CART123 powodowała całkowitą eradykację ludzkich komórek szpiku kostnego. Autorzy konkludują, że CART123 mogą być przydatne w leczeniu chorych na AML, na przykład jako nowa, skuteczna metoda leczenia kondycjonującego przed allo-HSCT.

\section{Ostra białaczka limfoblastyczna}

Wyniki leczenia dorosłych chorych na ALL były do niedawna daleko niesatysfakcjonujące, z prawdopodobieństwem wyleczenia rzędu 30\%. $\mathrm{W}$ ostatnich latach nastąpił istotny postęp, wynikający $z$ bardziej indywidualnego podejścia terapeutycznego. Obecnie wiadomo, $\dot{z}$ e odległe wyniki leczenia ALL zależą od efektywności terapii indukującej i konsolidującej w zakresie eradykacji MRD. U młodych dorosłych jest możliwe zastosowanie protokołów przypominających pod względem intensywności schematy stosowane $\mathrm{w}$ pediatrii. Wykonalność tej strategii była przedmiotem badania 2. fazy HOVON-70 [34] obejmującego chorych na ALL $\mathrm{Ph}(-)$ poniżej 40. roku życia. Protokół leczenia wyróżniał się stosowaniem dużych dawek metotreksatu $\left(5 \mathrm{~g} / \mathrm{m}^{2}\right)$ i L-asparaginazy. Prawdopodobieństwo OS i LFS po 26 miesiącach wyniosło odpowiednio $70 \%$ i $68 \%$.

U młodszych chorych podejmuje się próby intensyfikacji chemioterapii z uzależnieniem wskazań do HSCT od stanu MRD. W analizie 2 kolejnych protokołów grupy PALG wykazano poprawę 3-letniego prawdopodobieństwa OS z 32\% do $56 \%[35,36]$. Grupa północnowłoska wprowadziła do konsolidacji eskalowane i zależne od podtypu ALL dawki metotreksatu. Całkowite przeżycie po 1,5 roku wyniosło $79 \%$, a LFS - 66\% [37]. $Z$ kolei $\mathrm{w}$ badaniu niemieckim znacząco zwiększono dawki asparaginazy, uzyskując $67 \%$ OS po 3 latach [38].

Alternatywą dla eskalacji dawek tradycyjnych chemioterapeutyków jest zastosowanie nowych leków, o większej swoistości niszczenia komórek białaczkowych. Przykładem takiego podejścia może być stosowanie rytuksymabu w skojarzeniu $\mathrm{z}$ protokołem hyper-CVAD (cyklofosfamid, winkrystyna, doksorubicyna, deksametazon, metotreksat, Ara-C). U tak zwanych chorych dorastających (wiek 16-20 lat) terapia taka pozwoliła na uzyskanie 3-letniego prawdopodobieństwa OS rzędu 75\% [39]. Skojarzenie hyper-CVAD z ofatumumabem (humanizowanym przeciwciałem monoklonalnym anty-CD20; HuMax-CD20) jest również bezpieczną i wysoce skuteczną opcją terapeutyczną u chorych na ALL CD20+ [40]. Leczenie to umożliwia uzyskanie CR po pierwszym cyklu leczenia u około $94 \%$ chorych $z$ nowo rozpoznaną ALL CD20+. U żadnego pozostającego w remisji chorego nie stwierdzono obecności MRD metodą wielokomorowej cytometrii przepływowej. Inna alternatywą leczenia jest przeciwciało monoklonalne anty-CD22 sprzężone $z$ kalichemycyną (IO, inotuzumab ozogamycyny) [41]. Należy jednak podkreślić, że pewnym ograniczeniem tej metody jest hepatotoksyczność, a zwłaszcza wysoka (23\%) częstość występowania choroby żylno-okluzyjnej (VOD, veno-occlusive disease) u chorych leczonych następczo za pomocą allo-HSCT.

Inna forma immunoterapii to stosowanie przeciwciał bispecyficznych, przykładem których jest blinatumomab. Jedna $z$ jego domen wiąże się z CD19 na komórkach docelowych, a druga angażuje limfocyty $\mathrm{T}$ poprzez wiązanie $z \mathrm{CD} 3$. W badaniu 2. fazy zastosowanie tego leku w monoterapii pozwoliło na uzyskanie remisji molekularnej u 13 z 16 chorych $z$ obecnością MRD w fazie remisji hematologicznej [42]. Obiecujące wyniki uzyskano również u chorych na oporną i nawrotową ALL (R-R ALL, refractory-relapsed ALL) [43-45]. Monoterapia blinatumomabem pozwoliła na uzyskanie $\mathrm{CR}$ u 72\% chorych na R-R ALL; $92 \%$ uzyskało remisję molekularną na poziomie $10^{-4}$. Leczenie było dość dobrze tolerowane; u części chorych obserwowano odwracalną toksyczność neurologiczną pod postacią encefalopatii i/lub drgawek. Do innych najczęściej obserwowanych objawów niepożądanych należały: gorączka $(70 \%)$, bóle głowy (39\%), drżenie rąk (30\%) i zmęczenie (30\%).

Nową formą immunoterapii jest stosowanie limfocytów T uzyskanych za pomocą inżynierii genetycznej w leczeniu chorych na R-R ALL [45-49]; u większości pacjentów uzyskano remisję choroby i eliminację MRD. Do najczęstszych objawów niepożądanych należał tak zwany zespół uwalniania cytokin (CRS, cytokine release syndrome) objawiający się gorączką, bólami mięśniowymi, nudnościami i brakiem apetytu lub objawami neurologicznymi. W pojedynczych przypadkach obserwowano przemijające obniżenie ciśnienia tętniczego i/lub hipoksję. Objawom tym towarzyszy zwykle znamienny wzrost stężenia interleukiny $6 \mathrm{i}$ interferonu gamma pod postacią gorączki, spadku ciśnienia, hipoksji, zmian zachowania lub drgawek. Objawy niepożądane utrzymują się przeciętnie do 7 dni i ustępują po leczeniu steroidami lub tocilizumabem (przeciwciało monoklonalne przeciwko receptorowi dla interleukiny 6). Nasilenie objawów niepożądanych 
ściśle korelowało $z$ masą guza nowotworowego [50]. Trwają prace nad nową generacją CART skierowanych przeciwko antygenowi CD22 [51]. Leczenie za pomocą CTL019 stanowi obiecującą opcję terapeutyczną u chorych na R-R ALL, w tym również u chorych w nawrocie po allo-HSCT.

Odrębnego podejścia terapeutycznego wymagają chorzy na ALL $z$ obecnością chromosomu Filadelfia. W tej grupie obowiązkowym postępowaniem jest stosowanie inhibitorów kinazy tyrozynowej, zazwyczaj w skojarzeniu $z$ chemioterapią, a następnie dążenie do allo-HSCT [52-54]. W badaniu JALSG Ph + ALL202 schemat ten pozwolił na uzyskanie CR u 97\% chorych, a 3-letnie prawdopodobieństwo OS wyniosło 56\% - było ono wyższe u osób poddanych allo-HSCT (75\%) [55]. W badaniu NILG 09/00 odsetek CR wyniósł 92\%, a 5-letni OS - 38\%. Dalsza poprawa wyników leczenia jest spodziewana przy zastosowaniu inhibitorów kinaz tyrozynowych II generacji. Wstępne wyniki leczenia za pomocą DAS w skojarzeniu $z$ chemioterapią hyper-CVAD wskazują na możliwość uzyskania molekularnej CR u większości leczonych chorych [56].

\section{Podsumowanie}

Leczenie chorych na ostre białaczki musi mieć charakter zindywidualizowany. Przy wyborze formy terapii należy uwzględniać cechy biologiczne choroby, w tym obecność aberracji chromosomalnych, mutacji genowych, fenotypu, a także obecność czynników ryzyka nawrotu, w tym poziom MRD w różnych okresach terapii oraz wiek i stan biologiczny pacjenta. Rozwój różnych form terapii celowanej i immunoterapii, racjonalne wykorzystanie HSCT oraz opracowanie efektywnych protokołów leczenia o małej toksyczności dają szansę na istotną poprawę rokowania chorych na ostre białaczki.

\section{Piśmiennictwo}

1. Robak T, Wierzbowska A. Current and emerging therapies for acute myeloid leukemia. Clin. Ther. 2009; 31: 2349-2370.

2. Fernandez H.F., Sun Z., Yao X. i wsp. Anthracycline dose intensification in acute myeloid leukemia. N. Engl. J. Med. 2009; 361: 1249-1259.

3. Burnett A.K., Russell N.H., Hills R.K. i wsp. A randomized comparison of daunorubicin $90 \mathrm{mg} / \mathrm{m} 2 \mathrm{vs} 60 \mathrm{mg} / \mathrm{m} 2$ in AML induction: results from the UK NCRI AML17 trial in 1206 patients. Blood 2015 Apr 1. pii: blood-2015-01-623447 [złożone do druku].

4. Holowiecki J., Grosicki S., Giebel S. i wsp. Cladribine, but not fludarabine, added to daunorubicin and cytarabine during induction prolongs survival of patients with acute myeloid leukemia: a multicenter, randomized phase III study. J. Clin. Oncol. 2012; 30: 2441-2448.

5. Hills R.K., Castaigne S., Appelbaum F.R. i wsp. Addition of gemtuzumab ozogamicin to induction chemotherapy in adult patients with acute myeloid leukaemia: a meta-analysis of individual patient data from randomised controlled trials. Lancet Oncol. 2014; 15: 986-996.

6. Burnett A., Hills R.K., Russell N. i wsp. Reasons for survival improvement in core binding factor AML: a 25 year analysis of the UK MRC/NCRI AML Trials. 55th ASH Annual Meeting and Exposition (December 7-10, 2013) New Orleans. Blood 2013; 122: abstrakt 358.

7. Burnett A.K., Russell N.H., Hills R.K. i wsp. Optimization of chemotherapy for younger patients with acute myeloid leukemia: results of the medical research council AML15 trial. J. Clin. Oncol. 2013; 31: 3360-3368.

8. Löwenberg B., Pabst T., Vellenga E. i wsp.; Dutch-Belgian Cooperative Trial Group for Hemato-Oncology (HOVON) and Swiss Group for Clinical Cancer Research (SAKK) Collaborative Group. Cytarabine dose for acute myeloid leukemia. N. Engl. J. Med. 2011; 364: 1027-1036.

9. Kantarjian H.M., Thomas X.G., Dmoszynska A. i wsp. Multicenter, randomized, open-label, phase III trial of decitabine versus patient choice, with physician advice, of either supportive care or low-dose cytarabine for the treatment of older patients with newly diagnosed acute myeloid leukemia. J. Clin. Oncol. 2012; 30: 2670-2677.

10. Seymour J.F., Döhner H., Butrym A. i wsp. Azacitidine (AZA) versus conventional care regimens (CCR) in older patients with newly diagnosed acute myeloid leukemia ( $>30 \%$ bone marrow blasts) with myelodysplasia-related changes: a subgroup analysis of the AZA-AML-001 trial. 56th ASH Annual Meeting and Exposition (December 6-9, 2014), San Francisco. Blood 2014; 124: abstrakt 10.

11. Döhner H., Seymour J.F., Butrym A. i wsp. Overall survival in older patients with newly diagnosed acute myeloid leukemia (AML) with $>30 \%$ bone marrow blasts treated with azacitidine by cytogenetic risk status: results of the AZA-AML-001 Study. 56th ASH Annual Meeting and Exposition (December 6-9, 2014), San Francisco. Blood 2014; 124: abstrakt 621.

12. Schroeder T., Czibere A., Platzbecker U. i wsp. Azacitidine and donor lymphocyte infusions as first salvage therapy for relapse of AML or MDS after allogeneic stem cell transplantation. Leukemia 2013; 27: 1229-1235.

13. Burnett A.K., Russell N.H., Hunter A.E. i wsp.; UK National Cancer Research Institute AML Working Group. Clofarabine doubles the response rate in older patients with acute myeloid leukemia but does not improve survival. Blood 2013; 122: 1384-1394.

14. Platzbecker U., Avvisati G., Ehninger G. i wsp. Improved outcome with ATRA-arsenic trioxide compared to ATRA-chemotherapy in non-high risk acute promyelocytic leukemia - updated results of the Italian-German APL0406 trial on the extended final series. Results of the AZA-AML-001 study. 56th ASH Annual Meeting and Exposition (December 6-9, 2014), San Francisco. Blood 2014; 124: abstrakt 12.

15. Zhu1 H., Hu J., Chen L. i wsp. Long-term follow-up of survival, complications, arsenic retention and quality of life in patients with newly diagnosed acute promyelocytic leukemia treated with all-trans retinoic acid/arsenic trioxide combination therapy. 56th ASH Annual Meeting and Exposition (December 6-9, 2014), San Francisco. Blood 2014; 124: abstrakt 282.

16. Kayser S., Schlenk R.F., Londono M.C. i wsp.; German-Austrian AML Study Group (AMLSG). Insertion of FLT3 internal tandem duplication in the tyrosine kinase domain- 1 is associated with resistance to chemotherapy and inferior outcome. Blood 2009; 114: 2386-2392. 
17. Schlenk R.F., Döhner K., Krauter J. i wsp.; German-Austrian Acute Myeloid Leukemia Study Group. Mutations and treatment outcome in cytogenetically normal acute myeloid leukemia. N. Engl. J. Med. 2008; 358: 1909-1918.

18. Schlenk R.F., Kayser S., Bullinger L. i wsp. German-Austrian AML Study Group. Differential impact of allelic ratio and insertion site in FLT3-ITD-positive AML with respect to allogeneic transplantation. Blood 2014; 124: 3441-3449.

19. Kampa-Schittenhelm K.M., Heinrich M.C., Akmut F. i wsp. Quizartinib (AC220) is a potent second generation class III tyrosine kinaseinhibitor that displays a distinct inhibition profile against mutant-FLT3,-PDGFRA and-KIT isoforms. Mol. Cancer 2013; 12: 19.

20. Zarrinkar P.P., Gunawardane R.N., Cramer M.D. i wsp. AC220 is a uniquely potent and selective inhibitor of FLT3 for the treatment of acute myeloid leukemia (AML). Blood 2009; 114: 2984-2992.

21. Cortes J.E., Kantarjian H., Foran J.M. i wsp. Phase I study of quizartinib administered daily to patients with relapsed or refractory acute myeloid leukemia irrespective of FMS-like tyrosine kinase 3-internal tandem duplication status. J. Clin. Oncol. 2013; 31: 3681-3687.

22. Marcucci G., Geyer S., Zhao W. i wsp. Adding KIT inhibitor dasatinib (DAS) to chemotherapy overcomes the negative impact of KIT mutation/over-expression in core binding factor (CBF) acute myeloid leukemia (AML): results from CALGB 10801 (Alliance) 56th ASH Annual Meeting and Exposition (December 6-9, 2014), San Francisco. Blood 2014; 124: abstrakt 8.

23. Röllig C., Müller-Tidow C., Hüttmann A. i wsp. Sorafenib versus placebo in addition to standard therapy in younger patients with newly diagnosed acute myeloid leukemia: results from 267 patients treated in the randomized placebo-controlled SAL-Soraml trial. 56th ASH Annual Meeting and Exposition (December 6-9, 2014), San Francisco. Blood 2014; 124: abstrakt 6.

24. Gojo I., Karp J.E. New strategies in acute myelogenous leukemia: leukemogenesis and personalized medicine. Clin. Cancer Res. 2014; 20: 6233-6241.

25. Zhou J., Chng W.J. Identification and targeting leukemia stem cells: The path to the cure for acute myeloid leukemia. World J. Stem Cells 2014; 6: 473-484.

26. Smith D.B., Roboz J.G., Walter R.B. i wsp. First-in man, phase 1 study of CSL362 (anti-IL3R/anti-CD123 monoclonal antibody) in patients with $\mathrm{CD} 123+$ acute myeloid leukemia (AML) in CR at high risk for early relapse. 56th ASH Annual Meeting and Exposition (December 6-9, 2014), San Francisco. Blood 2014; 124: abstrakt 120.

27. Konoplev S., Lin .P, Yin C.C. i wsp. CXC chemokine receptor 4 expression, $\mathrm{CXC}$ chemokine receptor 4 activation, and wild-type nucleophosmin are independentlyassociated with unfavorable prognosis in patients with acute myeloid leukemia. Clin. Lymphoma Myeloma Leuk. 2013; 13: 686-692.

28. Chen Y., Jacamo R., Konopleva M. i wsp. CXCR4 downregulation of let-7a drives chemoresistance in acute myeloid leukemia. J. Clin. Invest. 2013; 123: 2395-2407.

29. Li X., Guo H., Yang Y. i wsp. A designed peptide targeting CXCR4 displays anti-acute myelocytic leukemia activity in vitro and in vivo. Sci. Rep. 2014; 4: 6610.

30. Zhang Y., Patel S., Abdelouahab H. i wsp. CXCR4 inhibitors selectively eliminate CXCR4-expressing human acute myeloid leukemia cells in NOG mouse model. Cell Death Dis. 2012; 3: e396.

31. Borthakur G., Nagler A., Ofran Y. i wsp. BL-8040, a peptidic CXCR4 antagonist, induces leukemia cell death and specific leukemia cell mobilization in relapsed/refractory acute myeloid leukemia patients in an ongoing phase iia clinical trial. 56th ASH Annual Meeting and Exposition (December 6-9, 2014), San Francisco. Blood 2014; 124: abstrakt 950.

32. Becker P.S., Foran J.M., Altman J.K. i wsp. Targeting the CXCR4 pathway: safety, tolerability and clinical activity of ulocuplumab (BMS-936564), an anti-CXCR4 antibody, in relapsed/refractory acute myeloid leukemia. 56th ASH Annual Meeting and Exposition (December 6-9, 2014), San Francisco. Blood 2014; 124: abstrakt 386.

33. Gill S., Tasian S.K., Ruella M. i wsp. Preclinical targeting of human acute myeloid leukemia and myeloablation using chimeric antigen receptor-modified T cells. Blood 2014; 123: 2343-2354.

34. Rijneveld A.W., van der Holt B., Daenen S.M. i wsp.; Dutch-Belgian HOVON Cooperative Group. Intensified chemotherapy inspired by a pediatric regimen combined with allogeneic transplantation in adult patients with acute lymphoblastic leukemia up to the age of 40. Leukemia 2011; 25: 1697-1703.

35. Giebel S., Stella-Holowiecka B., Krawczyk-Kulis M. i wsp.; Study Group for Adult ALL of the European Leukemia Net. Status of minimal residual disease determines outcome of autologous hematopoietic SCT in adult ALL. Bone Marrow Transplant. 2010; 4: 1095-1101.

36. Giebel S., Krawczyk-Kulis M., Kyrcz-Krzemien S. i wsp. Could cytogenetics and minimal residual disease replace conventional risk criteria in adults with $\mathrm{Ph}$-negative acute lymphoblastic leukaemia? Br. J. Haematol. 2009; 14: 970-972.

37. Bassan R., Rossi G., Pogliani E.M. i wsp. Chemotherapy-phased imatinib pulses improve long-term outcome of adult patients with Philadelphia chromosome-positive acute lymphoblastic leukemia: Northern Italy Leukemia Group protocol 09/00. J. Clin. Oncol. 2010; 28: 3644-3652.

38. Bassan R., Hoelzer D. Modern therapy of acute lymphoblastic leukemia. J. Clin. Oncol. 2011; 29: 532-543.

39. Thomas D.A., O'Brien S., Faderl S. i wsp. Chemoimmunotherapy with a modified hyper-CVAD and rituximab regimen improves outcome in de novo Philadelphia chromosome-negative precursor B-lineage acute lymphoblastic leukemia. J. Clin. Oncol. 2010; 28: 3880-3889.

40. Hoelzer D., Gökbuget N. Chemoimmunotherapy in acute lymphoblastic leukemia. Blood Rev. 2012; 2: 25-32.

41. Kantarjian H., Thomas D., Jorgensen J. i wsp. Results of inotuzumab ozogamicin, a CD22 monoclonal antibody, in refractory and relapsed acute lymphocytic leukemia. Cancer 2013; 119: 2728-2736.

42. Topp M.S., Gökbuget N., Zugmaier G. i wsp. Long-term follow-up of hematologic relapse-free survival in a phase 2 study of blinatumomab in patients with MRD in B-lineage ALL. Blood 2012; 120: 5185-5187.

43. Topp M.S., Gökbuget N., Zugmaier G. i wsp. Phase II trial of the anti-CD19 bispecific $\mathrm{T}$ cell-engager blinatumomab shows hematologic and molecular remissions in patients with relapsed or refractory B-precursor acute lymphoblastic leukemia. J. Clin. Oncol. 2014; 32: 4134-4140.

44. Klinger M., Brandl C., Zugmaier G. i wsp. Immunopharmacologic response of patients with B-lineage acute lymphoblastic leukemia to continuous infusion of $\mathrm{T}$ cell-engaging CD19/CD3-bispecific BiTE antibody blinatumomab. Blood 2012; 119: 6226-6233.

45. Maus M.V., Grupp S.A., Porter D.L., June C.H. Antibody-modified T cells: CARs take the front seat for hematologic malignancies. Blood 2014; 123: 2625-2635. 


\section{Hematologia 2015, tom 6, nr 1}

46. Lee D.W., Kochenderfer J.N., Stetler-Stevenson M. i wsp. T cells expressing CD19 chimeric antigen receptors for acute lymphoblastic leukaemia in children and young adults: a phase 1 dose-escalation trial. Lancet 2015; 385: 517-528.

47. Davila M.L., Riviere I., Wang X. i wsp. Efficacy and toxicity management of $19-28 z$ CAR T cell therapy in B cell acute lymphoblastic leukemia. Sci. Transl. Med. 2014; 6: 224-225.

48. Cruz C.R., Micklethwaite K.P., Savoldo B. i wsp. Infusion of donor-derived CD19-redirected virus-specific T cells for B-cell malignancies relapsed after allogeneic stem cell transplant: a phase 1 study. Blood. 2013; 122: 2965-2973.

49. Brentjens R.J., Davila M.L., Riviere I. i wsp. CD19-targeted T cells rapidly induce molecular remissions in adults with chemotherapy-refractory acute lymphoblastic leukemia. Sci Transl Med. 2013; 5: 177ra38.

50. Maude S.L., Barrett D., Teachey D.T., Grupp S.A. Managing cytokine release syndrome associated with novel T cell-engaging therapies. Cancer J. 2014; 20: 119-122.

51. Morgan R.A., FitzGerald D.J., Barrett D.M. i wsp. Anti-CD22-chimeric antigen receptors targeting B-cell precursor acute lymphoblastic leukemia. Blood 2013; 121: 1165-1174.
52. Chalandon Y., Thomas X., Hayette S. i wsp. Randomized study of reduced-intensity chemotherapy combined with imatinib in adults with $\mathrm{Ph}$-positive acute lymphoblastic leukemia. Blood $2015 \mathrm{Apr}$ 15 pii: blood-2015-02-627935 [złożone do druku].

53. Daver N., Thomas D., Ravandi F. i wsp. Final report of a phase II study of imatinib mesylate with hyper-CVAD for the frontline treatment of adult patients with Philadelphia chromosome positive $(\mathrm{Ph}+)$ acutelymphoblastic leukemia. Haematologica 2015 Feb 14. pii: haematol.2014.118588 [złożone do druku].

54. Ottmann O.G., Pfeifer H. Management of Philadelphia chromosome-positive acute lymphoblastic leukemia (Ph+ ALL). Hematology Am. Soc. Hematol. Educ. Program 2009; 2009: 371-381.

55. Mizuta S., Matsuo K., Maeda T. i wsp. Prognostic factors influencing clinical outcome of allogeneic hematopoietic stem cell transplantation following imatinib-based therapy in BCR-ABL-positive ALL. Blood Cancer J. 2012; 2: e72.

56. Ravandi F., O’Brien S., Thomas D. i wsp. First report of phase 2 study of dasatinib with hyper-CVAD for the frontline treatment of patients with Philadelphia chromosome-positive $(\mathrm{Ph}+)$ acute lymphoblastic leukemia. Blood 2010; 116: 2070-2077. 